\title{
Corporate Governance and Financial Performance of Quoted Companies in Nigeria
}

\author{
Halima Dahiru Mohammed \\ Department of Business Administration, Nile University of Nigeria, Abuja, Nigeria
}

\begin{abstract}
This study investigates the impact of corporate governance on the financial performance of selected companies quoted on the Nigerian stock exchange over the period $2014-2018$. The study uses a survey research design. The sample of the study covers fifteen companies from different sectors of the Nigerian stock exchange. Financial performance was captured by using return on investment, while the independent variable corporate governance was denominated by the percentage of attendance of board meeting and board size. All data were collected from the companies' annual reports. The companies' ages, firm and debt to equity ratio were used as control measures. The model was estimated using the Pooled Ordinary Least Squares estimation technique (POLS). Results from this study generally indicate that Board Activity and Board size have a significant positive impact on financial performance. The correlation matrix also shows that there is a positive significant linear relationship between the proxies of corporate governance and ROI. The study recommends that corporate governance should be given more priority in companies given its capacity to contribute to financial performance, as such all four null hypotheses are therefore rejected. Based on these results, shareholders are encouraged to request for access to adequate director's report at Annual General Meetings. Likewise, since Board activity and size have been shown to be strong predictors of firm performance, shareholders can make informed investment decisions by comparing attendance at board meetings and size of the boards. Further studies should consider other measures of the strength of the board such as board diversity and Number or frequency of meetings. Similarly, future research works can utilize larger sample.
\end{abstract}

Keywords: Corporate governance, Board Activity, Board Size, ROI

DOI: $10.7176 / \mathrm{EJBM} / 12-6-04$

Publication date: February $29^{\text {th }} 2020$

\section{Introduction}

Recent cases of corporate scandals such as Volkswagen's cheating emission tests in September 2015 and Exxon's deliberate misinformation of the public for decades as well as earlier celebrated cases of corporate governance failures such as that of Enron Corporation in October 2001, Xerox in June 2002, WorldCom in march 2002, Adelphia in April 2002, and Global crossing in February 2002 have turned the world's attention to the broader problem of irresponsibility of many corporates and the imperativeness of establishing reliable corporate governance framework that protects the interest of all stakeholders thereby bringing back people's trust in corporations.

OECD (2004) noted that the purpose of corporate governance is to help build an environment of trust, transparency and accountability necessary for fostering long-term investment, financial stability and business integrity, thereby supporting stronger growth and more inclusive societies. According to PWC (2015) some of the benefits for corporate governance are that firstly it brings about higher confidence among all stakeholders in the business's ability to generate value in the future. Secondly, it endows organisations with strategic advantage over their competitors. Thirdly, organizations with good corporate governance framework develop greater resilience both to sudden shocks and long-term change. Ultimately, all these benefits come together in a single, invaluable asset which is higher trust. An organisation that is evidently well-governed will generate stronger trust both internally and externally, this translates to competitive advantage for the company over its competitors.

McKinsey and Company (2002) in a research cited in Adams and Mehran (2003) noted that the study showed how much investors valued the presence of good governance. According to the report most investors in Malaysia showed the desire to pay more for the shares of a well governed company. The research also showed that the investors were ready to pay a mean premium within the limit of $20 \%$ to $25 \%$.

This topic is of significance to theorists giving the divergence of opinion in normative literature on the effect of corporate governance on financial performance. A school of thought believe that corporate governance does not necessarily influence the performance of corporates while others are of the view that corporate governance can be a potent means of influencing corporate performance.

Also this work is of relevance to empirical literature given the divergent conclusions of existing studies on the impact of corporate governance on financial performance. While numerous works conducted on this topic the results have been divergent some have concluded that there exists a positive relationship while others have declared that there is no verifiable effect of corporate governance on firm performance.

This study therefor will be fill the research gaps. Firstly, this research adopts board attendance as a measure 
of corporate governance and ROI as a measure of financial performance. Secondly this study investigates the intervening effect of variables such as age of company, debt to equity ratio of the firms and firm size.

\subsection{Research questions}

1. To what extent does board size affect the ROI of quoted companies in Nigeria?

2. Does attendance of board meetings have a significant effect on the ROI of quoted companies in Nigeria?

3. Is there a significant linear relationship between Board Activity and ROI of firms?

4. To what degree does Board Size affect the ROI of firms?

\subsection{Research objectives}

1. To investigate the effect of board size on the ROI of quoted companies in Nigeria

2. To study the effect of attendance of board meetings on the ROI of quoted companies in Nigeria

3. To ascertain whether or not there exists a correlational relationship between Board Activity and ROI.

4. To determine whether there exists a significant linear relationship between Board Size and ROI.

\section{Literature Review}

\subsection{Conceptual Framework}

\subsubsection{Corporate Governance}

Corporate governance is a mechanism which tries to eliminate the principle-agent problem by ensuring accountability to stakeholders (Chaudhary\& Gakhar 2018). Du Plessis, Bagaric et al. (2010) suggested that the ultimate goal for corporate governance should be toward the optimisation of efficiency and productivity, hence define corporate governance as: The system of regulating and overseeing corporate conduct and of balancing the interests of all internal stakeholders and other parties who can be affected by the corporation's conduct in order to ensure responsible behaviour by corporations and to achieve the maximum level of efficiency and profitability for a corporation (Du Plessis, Bagaric et al. 2010, p. 10).

According to Sullivan (2009) corporate governance is considered to be a process in which affairs of the firm are directed and controlled so as to protect the interest of all stakeholders. Oman (2001) defined corporate governance as a term refers to the private and public institutions that include laws, regulations and the business practices which governs the relationship between the corporate managers and the stakeholders.

OECD in 1999 defined corporate governance as "Corporate governance is the system by which business corporations are directed and controlled. The corporate governance structure specifies the distribution of rights and responsibilities among different participants in the corporation, such as, the board, managers, shareholders and other stakeholders, and spells out the rules and procedures for making decisions on corporate affairs. By doing this, it also provides the structure through which the company objectives are set, and the means of attaining those objectives and monitoring performance."

\subsubsection{Participants in Corporate Governance}

Adam Smith in his notable work, The Wealth of Nations, published in 1776, concluded that the corporate form of organisations, which views the organisations as a separate legal entity. This has a number of implications, one of the most important of which is that the company, not the shareholders, owns the company assets, and the company is responsible for its liabilities. Only upon liquidation may the shareholders be entitled to the remaining assets after the settlement of company debt. This gives the company a lot powers and exposes the shareholders to the risk of losing their investment, hence the need for corporations to be closely monitored.

The legal control and ownership of a limited liability company resides in the shareholders who are typically believed to be the owners of the company (Chassagnon \& Hollandts 2014). They exercise this responsibility at general shareholder meetings. However, the shareholders delegate their powers to a board of directors whom they elect. Those directors are held responsible for the activities of the company, and are required to render account of stewardship on the affairs of the company to the owners.

In sequence, the board of directors engage the services of employees who are expected to perform the dayto-day activities of the organisation. The employees act on behalf of the directors and create direct personal liability for company directors. This is why although auditors, and company executives are also dealt with in many corporate governance codes, by far, the overwhelming majority of recent corporate governance reform efforts, focused on the board of directors. (Vagnuer, 2017)

\subsubsection{Corporate Governance framework}

Corporate governance framework are mechanisms put in place to ensure good governance. They can be broadly categorized into two. These include: external corporate governance framework and internal corporate governance framework.

\section{External Corporate Governance Framework}

The external corporate governance framework provides rules, guidance and controls arising outside an organization that are intended to influence the decisions, actions and behaviour that occur within it. This framework is made up 
of four complex and interrelated elements. The system of intended or emergent processes that provide the external guidance, rules and controls that seek to influence actions and behaviours within corporate bodies (Vagnuer 2017). These include

i. Laws and regulations

ii. Codes of best practice

Laws and regulation.

These are legal requirements binding on companies which arise from the acts of parliament and court pronouncements. The table below shows specific company legislation that have at some point been binding on companies domiciled in Nigeria.

Table 1: List of Nigerian Promulgations on Company Regulation

\begin{tabular}{|l|l|}
\hline & Law and regulation \\
\hline 1 & Company Ordinance of 1912 \\
\hline 2 & Companies Amendment and Extension Act of 1917 \\
\hline 4 & Companies Ordinance of 1922 \\
\hline 7 & Companies Ordinance of 1929,1941 and 1954 as amended \\
\hline 8 & Che 1968 Companies Act \\
\hline
\end{tabular}

Source: Companies and Allied Matters Decree (1990)

Codes of Best Practices

A code of best practice is a set of non-binding principles, standards and practices that have been recommended by a distinguished body and that relate to the internal governance of companies

(Vagnuer, 2017). The following are some of the key codes of best practices issued by bodies in Nigeria.

Table 2: List of Corporate Governance Codes in Nigeria

\begin{tabular}{|c|c|c|}
\hline & CODE OF BEST PRACTICE IN NIGERIA & ISSUING BODY \\
\hline 1 & Code of Corporate Governance 2018 & $\begin{array}{llll}\text { Financial } & \text { Reporting } & \text { Council of } \\
\text { Nigeria } & \end{array}$ \\
\hline 2. & Code of Corporate Governance 2016 & $\begin{array}{l}\text { Financial Reporting Council of } \\
\text { Nigeria }\end{array}$ \\
\hline 3. & $\begin{array}{l}\text { Code of Corporate Governance for the Telecommunication } \\
\text { Industry } 2016\end{array}$ & $\begin{array}{l}\text { the Nigerian Communications } \\
\text { Commission }\end{array}$ \\
\hline 4 & $\begin{array}{l}\text { Code of Corporate Governance for Banks and Discount Houses in } \\
\text { Nigeria } 2014\end{array}$ & Central Bank of Nigeria \\
\hline 5 & Nigerian Communications Commission Code 2014 & $\begin{array}{l}\text { Nigerian } \\
\text { Commission }\end{array}$ \\
\hline 6 & $\begin{array}{l}\text { Code of Corporate Governance for Public Companies in Nigeria } \\
2011\end{array}$ & Securities and Exchange Commission \\
\hline 7 & $\begin{array}{l}\text { Code of Good Corporate Governance for Insurance Industry in } \\
\text { Nigeria } 2009\end{array}$ & National Insurance Commission \\
\hline 8 & $\begin{array}{l}\text { Code of Corporate Governance for Licensed Pension Fund } \\
\text { Operators } 2008\end{array}$ & National Pension Commission \\
\hline 9 & Central Bank of Nigeria Code 2006 & Central Bank of Nigeria \\
\hline 10 & Securities and Exchange Commission Code 2003 & Securities and Exchange Commission \\
\hline
\end{tabular}

Source: Financial Reporting Council Code of Corporate Governance 2018

Internal Corporate Governance Framework

The internal corporate governance framework focus on internal control practices, accountability and the finance function. Internal corporate governance are measures put in place by individual organisations to ensure that the external objectives of public policy and behavioural norms are achieved. In other words, there exists a connection between recommendations and mandates from external governance framework and internal governance practice. The Board of directors are saddled with the responsibility of providing internal governance mechanisms by formulating and ensuring compliance with company-wide policies which should ultimately result in improved firm performance.

\subsubsection{Financial Performance}

Financial performance represents the company's financial condition over a specific time period that includes the collection and use of funds measured by several indicators of capital adequacy ratio, liquidity, leverage, solvency, and profitability. Financial performance is the company's ability to manage and control its resources (Van Horne \& Wachowicz 2001).

Financial performance is a measure of a firm's capacity to create profit, profit or revenue. Financial performance can be evaluated from the information provided in the financial statements. The financial statements 
consist of; (a) Balance Sheet, (b) Income, (c) Cash flow, (d) Changes in capital (Fatihudin and Mochklas, 2018).

There are several ratios to measure the company's financial performance and these ratios can be broadly classified into five categories such as liquidity ratio, profitability ratio, solvency ratio, efficiency ratio, and leverage ratio. Profitability ratios measure the performance of the company in terms of the profit generated over the period being considered. ROI (Return on Investment), ROE (Return on Equity), ROA (Return on Assets), EBIT (Earnings Before Interest and Tax) profit are examples of profitability ratios.

Return on Investment (ROI) is one of the most popular performance measurement and evaluation measures adopted in firm performance evaluation. ROI is reliable measure for evaluating financial performance and making informed decisions. At present, ROI is widely recognized and accepted in business and financial management in both the private and public sectors (Botchkarev and Chiong 2011)

To calculate ROI, the difference between benefit (return) of an investment (i.e.the net profit for the period) and the cost of investment (i.e. capital employed by the company in the period) is divided by the cost of the investment; the result is expressed as a percentage or a ratio.

$$
R O I=\frac{\text { Gain from investment }(\text { Net profit })-\text { cost of investment }}{\text { cost of investment }(\text { capital employed })} \times \frac{100}{1}
$$

ROI has become a popular performance measure for the following reasons. Firstly, ROI is simple to understand and to compute. Secondly ROI encourages cost efficiency and focuses on one of the main corporate metrics - profitability. Thirdly ROI, being based on accounting records, provides objective results. Fourthly ROI allows comparisons of profitability between dissimilar businesses/projects.

\subsubsection{Corporate Governance and Financial Performance}

An effective board not only provides strategic guidance to the company, it also promotes culture of ethical practice and good governance. The Board who are the middlemen between the owners of the company and the managers of the company are expected to perform their supervisory role in a bid to ensure that the managers always act in favour of the owners of the company.

Literature provides different measures for evaluating the effectiveness of the board in its disposal of its duties. Sheikh N. H., Wang Z. and Khan S. (2013) adopted board size as a measure of the capacity of the board in performing its duties, while Shiah-Hou S. R. and Cheng C. W. (2012) relied on directors' remuneration. Arouri H. Et al (2014) believed that a good measure of board efficiency is ownership pattern. Literature also suggests that increasing the frequency of board meetings leads to improved performance. Ntim (2009) propounded that a higher frequency of board meetings would breed better managerial supervison, and consequently resulting in improvement in the firm's financial performance.

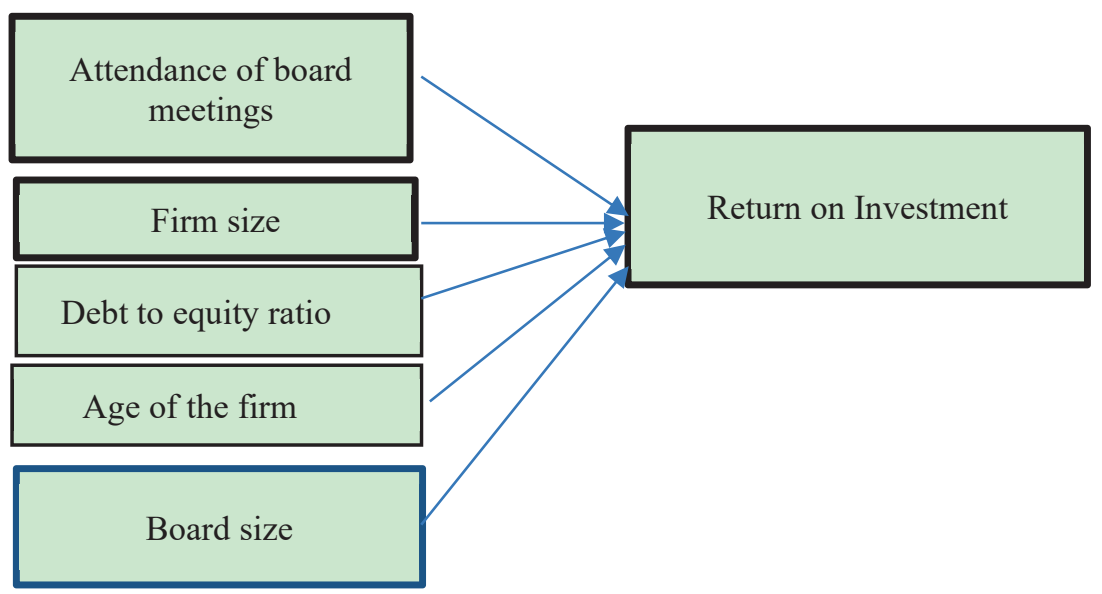

Figure 1: Conceptual framework

Source: Author's own compilation

\subsection{Theoretical framework}

According to Rashid (2011) there are many theories that can be adopted in understanding corporate governance concept. However, there are two widely discussed theories and these are principal-agent theory (or agency theory) and stakeholder theory (Vagnuer, 2017). This study is underpinned by the principal-agent theory.

\subsubsection{Principal-Agent Theory}

This study's conceptual framework and hypotheses are based on agency theory because it is the most widely used theoretical framework for analyzing corporate governance (Fama \& Jensen, 1983; Jensen \& Meckling, 1976). The origin of the agency theory is often attributed to Berle and Means (1932) and Adam Smith (1776). According to this theory, a problem arises due to the fact that the owners of the firm's resources are not the managers (Grossman \& Hart,1986). Letza, Sun and Kirkbride (2004) succinctly describes the agency problem as arising because 
directors were not likely to be as prudent with other people's money as with their own.

These contracting relationship between the owners and directors is known as the agency relationship, which is ' $a$ contract under which one or more persons (the principal(s)) engage another person (the agent) to perform some service on their behalf which involves delegating some decision making authority to the agent' (Jensen and Meckling, 1976: 308).

The agency relationship can be a problem because the directors who are the agent may not always act in the best interests of the owners who are the principals. In a bid to solving the agency problem agency costs have to be incurred by the principals. The agency cost includes costs of monitoring the agent, costs incurred by the agent due to bonding, and the cost incurred by the principal in providing incentives for the agent

One implication of the agent -principal relationship is that the managers become more informed about the firm than the owners. This results in what is called information asymmetry where agents have better access to information than shareholders. One way principals can attempt to overcome the challenge of information asymmetry is by monitoring management. However, for individual principals monitoring is costly. The overall costs of information-gathering can be reduced by putting in place a reporting system which meets the information requirement of all shareholders.

\subsection{Empirical review}

Several studies revealed mixed findings in relation to the impact of corporate governance on firm performance. On one hand are those whose findings reveal that corporate governance has a negative impact on performance. Some of these studies are reviewed as follows:

Samson and Tarila (2014) examined the impact of corporate governance on financial performance in Nigerian banks who adopted the 2012 CBN code. Secondary data was collected from the yearly-published reports of the listed banks in Nigeria. Model estimation technique used was regression analysis. Corporate governance was denominated using board size and board composition (the ratio of non-executive directors to total directors), and corporate governance disclosure index. While financial performance was represented with return on equity (ROE) and return on asset (ROA). The results of the study showed that a positive relationship exists between the corporate governance variables and the performance variables.

Similarly, Siddiqui (2015) investigated the relationship between corporate governance and firm performance by conducting a meta-analysis of 25 previous studies. The methodology used is the meta-analysis technique. The study represents the external governance mechanisms by anti-takeover provisions and market value of firm performance was measured by Tobin's Q and market to book value. The author found that the external governance mechanism (anti-takeover provisions) exerts more influential effect on firm performance than both external and internal governance together.

Arora and Sharma (2016) examined the impact of corporate governance on firm performance for a large representative sample of companies drawn from more than 20 important industries of the Indian manufacturing sector for the period 2001-2010. Several alternative specifications and estimation techniques are used for analysis purposes, including system generalized methods of moments. Findings reveal that larger boards are associated with a greater depth of intellectual knowledge, which in turn leads to improved decision-making and better performance. On the other hand, the results show that return on equity and profitability are not related to corporate governance indicators. The results also suggest that CEO doubling as Chairman does not affect firm performance. The researchers conclude that companies that comply with good corporate governance practices can expect to achieve higher accounting and market performances.

Haque, Faizul, Arun, and Thankom G. (2016) examined the influence of firm-level corporate governance on financial performance of the listed firms in Bangladesh. Data collection was done using a questionnaire surveybased corporate governance index (CGI), which focused on three variables - shareholder rights, independence and responsibilities of the board and management, and financial reporting and disclosures. The study results confirm the postulation of the principal-agent theory, with a statistically significant positive relationship between a firm's corporate governance quality and its valuation, although the relationship between firm level corporate governance and operating performance appears indecisive. Paniagua, Rivelles and Sapena (2018) studied how corporate governance and ownership structure impact on the financial performance of firms. We estimated this relationship using QCA (qualitative comparative analysis). Model estimation was carried out using complementary linear and non-linear multiple regression analysis. The panel data used in the study covered 1207 companies from 59 countries across 19 sectors for the period 2013 to 2015. The study found a negative relationship between owner dispersion, board member dispersion and payment of dividend and Return on Asset.

Alley, Adebayo and Oligbi.(2016) studied the nature of relationship between corporate governance and financial performance. . The results agree with the findings of most previous studies that corporate governance significantly affects financial performance. Board skills, board composition and management skills enhanced financial performance indicators - return on equity (ROE), return on asset (ROA) and net profit margin. in many occasions, significantly. Board size and audit committee size did not, and were found to be capable of undermining 
financial performance. More importantly, financial performance did not significantly affect corporate governance. On the basis of the VEC model, the researchers conclude on a unidirectional causality in the connection between corporate governance and financial performance.

Jonty, Leon M, Hendrik and Elda. (2018) investigated empirically the existence of industry nuances in the relationship between corporate governance and financial performance of companies listed in the Johannesburg Stock Exchange. A sample of 90 companies from the five largest South African industries, covering a 13-year period from 2002 to 2014 (1170 firm-year observations) was examined with three estimation techniques. Results from the study indicate that two key trends emerged from this study. First, the relationship between corporate governance and company performance differed from industry to industry. Second, the relationship between corporate governance and company performance also reacts to changes from steady to non-steady periods.

Chaudhary and Gakhar (2018) investigated how corporate governance contribute to firms financial performance. Board size and the frequency of boards meetings were adopted as measures of corporate governance while firms' financial performance was represented with ROA, ROE, and Earnings per share, Price Earnings ratio. The research design of the study was descriptive-cum- diagnostic. The top five automobile companies in India were selected on the basis of market capitalization for the period from 2009 to 2013. The study was based on secondary data collected from PROWESS database. Multiple regression analysis was carried out. Both board size and frequency of board meetings were not statistically significant for all performance measures.

Patel (2018) studied the impact of corporate governance and performance of companies in selected sectors of cement and food and personal care products in Pakistan for the period between 2010 to 2015. Quantitative research methodology was used while Pearson's correlation and regression methods were used for data analysis. The study discloses that there is a significant negative relationship between firm's performance and share ownership by directors. In other words, increase in the directors' ownership results in reduced financial performance. Similarly, there is a significant negative relationship found between the firm's performance and number of independent directors. However, there is an insignificant relationship between performance and concentration of the share ownership.

Akinleye and Fajuyagbe (2019) in their focused on the impact of corporate governance and performance of selected Nigerian multinational firms from 2012 to 2016. They adopted board size, activism and committee activism as the proxies of corporate governance and used return on asset and firm growth rate as proxies of firm financial performance. Using static panel estimation techniques, secondary data collected from four multinational firms were analyzed. Results indicate that while board size and board activism exerted significant negative impact on return on asset, committee activism exerted insignificant impact. The results of the study further showed that board size and board activism exert insignificant negative impact on firm's growth rate, while committee activism insignificantly spurs firm's growth rate.

On the basis of the above studies, it can be inferred that there is no conclusive relationship of board size and frequency of board meetings with financial performance of the firms. Hence a need to find out this relationship within the Nigerian context. None of the studies considered the intervening effect of control variables such as firm size, age of the company and importantly debt to equity ratio. Secondly, this research work adopts as its estimation technique the Pooled Ordinary Least squares (POLS) method while robustly. This is expected to result in a more reliable result.

\section{Methodology}

This work adopts the survey research design to ascertain the degree of the causal relationship which exists between the attendance of board meetings and audit committee meetings (being two measures of the strength of corporate governance) and ROI (as a proxy of firm performance). Panel Data was obtained on 15 quoted companies over the 5-year period from 2014 to 2018 . The source of data for the study were the companies' annual reports.

The study utilizes the Pooled Ordinary Least Square POLS estimation technique. The POLS is an empirical model which is based on the Gauss Mankov assumptions of a constant variance of the error term and a mean error term that equals zero. Being a time series data, the data set will tend to be characterized by the correlation of subsequent error terms (i.e. autocorrelation) whereby contemporaneous error terms include delayed copy of itself. In effect, the standard error tends to be overestimated and this reduces the statistical significance of the estimated coefficients. To address this, this study adopts the Newey West (1987) robust standard error measure which insulates the computed standard error from the effects of autocorrelation and as such allows for a fair assessment of the statistical significance of regression estimates.

Apart from a regression analysis, this work also evaluates the degree of significance of the correlation coefficients in order to determine the predictability of firm value given certain changes in the two proxies of corporate governance namely attendance of board meeting and attendance of audit committee meeting. Summary statistics such as to capture the character. 


\section{Model Specification}

The primary set of objectives of this study which forms the basis of the first and second hypotheses, is to find the causal relationship between the proxies of corporate governance and firm performance. To achieve this, firm performance is modelled as the dependent variable while Attendance of board meetings $A B S$, and Board Size $B D S$ are stated as two primary explanatory variable while other control variables such as $A S S, D E R, A G E$ are included as mediating variables. Afterwards, the variables are operationalized by imputing them into the model.

The implication of this is that the model becomes a level-level model, the coefficients of which will rather measure unit change in the dependent variable due to a level change in the regressors.

$R O I=f(A B M, B D S, A S S, D E R, A G E)$

$R_{O I, t}=\alpha+\beta_{1} A B M_{i, t}+\beta_{2} B D S_{i, t}+\beta_{3} A S S_{i, t}+\beta_{4} D E R R_{i, t}+\beta_{5} A G E_{i, t}+\mu_{i, t . \ldots}$

Table 3: Description of Variables and Parameters

\begin{tabular}{|l|l|l|}
\hline Variables & Definition & \\
\hline ROI & Return on Investment & Fir m performance \\
\hline ABM & $\begin{array}{l}\text { Attendance of Board meetings/Board } \\
\text { Activity }\end{array}$ & Corporate governance \\
\hline BDS & Board Size & Corporate governance \\
\hline ASS & Asset & Company size \\
\hline DER & Debt Equity Ratio & Capital Structure \\
\hline$A G E$ & Number of years of operation & Age \\
\cline { 1 - 2 } $\boldsymbol{\mu}_{\mathbf{i}, \mathbf{t}}$ & Error term & $\begin{array}{l}\text { Measure of variation in the dependent variable due to } \\
\text { unobserved variables }\end{array}$ \\
\cline { 1 - 2 } & Constant & \multicolumn{2}{|l}{} \\
\hline $\boldsymbol{\beta}_{\mathbf{1}}-\boldsymbol{\beta}_{\mathbf{5}}$ & Parameters of the Model &
\end{tabular}

The second set of objectives of this study is to determine the existence and extent of the linear relationship between each of the measures of corporate governance on the one hand and firm performance on the other hand. The levels of significance would also be ascertained, using the Pearson correlation matrix. It is expected that where any two variables are significantly correlated, the correlation coefficient $(\mathrm{R})$ will exceed 0.5 and the $t$ statistic should exceed

\section{Results and Discussions. \\ 4.1 Result \\ Descriptive Statistics}

Table 4: Result of Summary Statistics

\begin{tabular}{|l|l|l|l|l|l|}
\hline Variable & $\mathrm{N}$ & Mean & SD & Min & Max \\
\hline ROI & 59 & 0.0900012 & 0.2014434 & -0.873 & 0.866 \\
\hline ABM & 59 & 0.8816181 & 0.1002996 & .6166667 & 1 \\
\hline BDS & 59 & 9.661017 & 2.616988 & 6 & 16 \\
\hline ASS & 59 & 150000000000 & 391000000000 & 565000000 & 1720000000000 \\
\hline DER & 59 & 0.5390461 & 0.972735 & -2.594 & 3.374 \\
\hline AGE & 59 & 33.71186 & 21.82458 & 1 & 73 \\
\hline
\end{tabular}

\section{Source: Researcher's Computation}

This work utilized a total of 59 observations on 15 quoted companies, implying that the data is an unbalanced panel. This however has no effect on the results obtained therefrom. The summary statistics entail the average ROI, Attendance at board meetings, Board size, Company Size, Debt-Equity Ratio, Age and Proportion of board meetings attended by directors of the 15 firms studied. While the mean ROI is $9 \%$, the average attendance by board members in all sampled companies is $88.16 \%$, the average board size is approximately 10 members. Of the two proxies of corporate governance, Board size returns a higher degree of variation with a standard deviation of 2.616988 which exceeds the standard deviation of attendance of Board meetings. The distribution of attendance of board meeting is fairly normal as over $95 \%$ of the 59 observations fall within 2 standard deviations.

The company with the highest ROI recorded 0.3794 , the minimum was however -0.873 which denotes negative returns on Investment. The largest company in the sample, in terms of size, has assets worth N172billion while the minimum has assets which are by book value worth N565million. The company which has been in operation for the longest period of time had operated for 73 years in the year sampled. 


\section{Regression}

H01: There is no significant causal relationship between $\mathrm{ABM}$ and $\mathrm{ROI}$

$\mathrm{HO}_{2}$ : There is no significant causal relationship between BDS and ROI

Table 5: Result of the Regression result.

\begin{tabular}{|c|c|c|c|}
\hline & Coefficient & t-Statistics & Prob-value \\
\hline $\mathrm{C}$ & $\begin{array}{l}0.5276683 \\
(0.266266)\end{array}$ & -1.98 & 0.053 \\
\hline ABM & $\begin{array}{l}0.4912553 \\
(0.2578226)\end{array}$ & 1.91 & 0.062 \\
\hline BDS & $\begin{array}{l}0.022623 \\
(0.0132034)\end{array}$ & 1.71 & 0.092 \\
\hline ASS & $\begin{array}{l}-0.0000000000000625 \\
(0.0000000000000907)\end{array}$ & -0.69 & 0.494 \\
\hline DER & $\begin{array}{l}-0.0570531 \\
(0.0266)\end{array}$ & -2.14 & 0.037 \\
\hline AGE & $\begin{array}{l}0.000182 \\
(.00117)\end{array}$ & 0.16 & 0.877 \\
\hline $\mathbf{F}$ & 2.40 & & \\
\hline $\operatorname{Prob}(\mathbf{F})$ & 0.0492 & & \\
\hline $\mathbf{R}^{2}$ & 0.1846 & & \\
\hline
\end{tabular}

\section{Source: Researcher's Computation.}

The regression results show that the ROI attains a minimum value of 0.5276683 which represents the return on Investment when all regressors within the model are equated to zero. The parameter estimate of ABMAttendance at Board Meetings, is 0.4912553 which is positive and statistically significant at $10 \%$ significance level. Also, the coefficients of the other four right hand side variables - BDS, ASS, DER and AGE are 0.022623, $\mathbf{- 0 . 0 0 0 0 0 0 0 0 0 0 0 0 0 6 2 5 , ~} \mathbf{- 0 . 0 5 7 0 5 3 1 , 0 . 0 0 0 1 8 2 ~ r e s p e c t i v e l y . ~ A p a r t ~ f r o m ~ t h e ~ c o n s t a n t ~ t e r m , ~ t w o ~ o t h e r ~ e s t i m a t e s ~ a r e ~}$ statistically significant at $10 \%$ level of significance while a third is significant at $5 \%$ level of significance.

As such, if ABM is considered as a good measure of corporate governance, and a percentage increase in ABM seems to bring about a $49.12 \%$ increase in the ROI of firms, we can conclude that corporate governance has a positive effect on firm performance. Likewise, each additional member that increases board size leads to an increase in ROI by $2.226 \%$. Importantly, the model is considered to be statistically significant with an F statistic of 2.4 and a prob value of 0.0492 which is less than 0.05 and so implies that the model is statistically significant. The $\mathrm{R}^{2}$ shows that $18.46 \%$ of the variation in ROI is accounted for by changes in the regressors.

As such we reject the null hypothesis that there is no significant causal relationship between firm performance and Attendance of Board meetings. In the same vein. The null hypothesis that there is no significant relationship between firm performance and Board size is also rejected.

Correlation

$\mathrm{HO}_{3}$ : There is no significant linear relationship between ABM and ROI

$\mathrm{HO}_{4}$ : There is no significant linear relationship between BDS and ROI

Table 6: Results of Correlation Matrix

\begin{tabular}{|l|l|l|l|l|l|l|}
\hline & ROI & ABM & BDS & ASS & DER & AGE \\
\hline ROI & $\mathbf{1}$ & & & & & \\
\hline ABM & $\begin{array}{l}\mathbf{0 . 2 6 7 6} \\
(\mathbf{0 . 0 4 0 4 )}\end{array}$ & $\mathbf{1}$ & & & & \\
\hline BDS & $\begin{array}{l}\mathbf{0 . 2 1 7 0} \\
(\mathbf{0 . 0 9 8 8})\end{array}$ & $\begin{array}{l}\mathbf{0 . 0 8 2 8} \\
(\mathbf{0 . 5 3 3 1 )}\end{array}$ & $\mathbf{1}$ & & & \\
\hline ASS & 0.1662 & 0.2266 & 0.6700 & $\mathbf{1}$ & & \\
\hline DER & $\mathbf{- 0 . 2 6 9 5}$ & $\mathbf{- 0 . 0 8 8 1}$ & $\mathbf{0 . 0 5 3 7}$ & $\mathbf{- 0 . 1 2 3 1}$ & $\mathbf{1}$ & \\
\hline AGE & $\mathbf{0 . 0 6 4 0}$ & $\mathbf{0 . 0 9 7 6}$ & $\mathbf{- 0 . 0 5 7 9}$ & $\mathbf{0 . 0 6 1 3}$ & $\mathbf{- 0 . 1 6 2 9}$ & $\mathbf{1}$ \\
\hline
\end{tabular}

\section{Source: Researcher's Computation}

The pairwise correlational matrix shows the extent of the linear relationship between the variables studied. The result above proves that there exists a positive but weak relationship between ROI (a measure of firm profitability) and Attendance of board meetings, where $r=+0.2676$, and as the $p$ value $(0.0404)$ is lower than 0.05 the linear relationship between ABM and ROI is said to be statistically significant at $95 \%$ confidence interval. The second proxy of corporate governance used in this study- BDS proves also to have a significantly positive but weak relationship with ROI, having $\mathrm{r}=0.2170$, and a prob-value of 0.0988 . The relationship between the two proxies of corporate governance $\mathrm{ABM}$ and BDS is however statistically insignificant at the $90 \%$ level of significance. 
Hence, we reject the null hypothesis three $\left(\mathrm{HO}_{3}\right)$ that there is no significant linear relationship between Attendance of Board Meetings(ABM) and firm performance (ROI). Also, we reject the null hypothesis four $\left(\mathrm{H}_{4}\right)$ that there is no significant relationship between Board Size (BDS) and Firm Performance(ROI).

\section{Conclusion}

This study sought to examine the effect of Board Activity and Board Size on the Firm Performance. The Board of Directors in any organization is not only a lynch pin which determines the strategic outlook of the organization and steers its activities. but a fundamental element of the corporate governance system. Its major responsibilities are to connect the owners of the organization to the management, to orientate, oversee and advise the management on carry on the business in a manner that protects the interest of the shareholders. The theoretical framework upon which this work rests is the Principal-Agent theory, which highlight the important role the Board plays in ensuring the interest of shareholders (i.e the principal) are protected by their representatives who are collectively referred to as the board

In the course of this study, several studies were reviewed and the common purpose was to establish or validate the claim that there exists a causal and or correlational relationship between Board effectiveness, activity, size on the one hand and financial performance of the firm on the other hand. Different results have been obtained so while some studies reckon that Board size and activity are not significant in determining firm performance, others opine on the contrary. This study however found that Board activity and size both affect firm performance significantly.

The level of Board Activity was proxied by attendance of board meetings, while firm performance was measured by the ROI. The model also included other variables such as Board size, Total Asset, Debt-Equity Ratio and the Number of years of operation of the firms. Stylized data obtained from the annual reports of the firms were utilized in determining the causal and correlational relationships between the dependent variable and the regressors. The results obtained show that both $\mathrm{ABM}$ and BDS have a significant positive effect on firm performance, to such an extent that a $1 \%$ improvement in attendance of board meetings will bring about a 0.4912 increase in firm performance. In the case of other regressors, results show that a $1 \%$ increase in both DER brings about a reduction of 0.527 in the ROI of the firm. The coefficients estimated for AGE and ASS are statistically insignificant at $95 \%$ confidence interval.

The correlation matrix shows that there exists a statistically significant linear relationship between $\mathrm{ABM}$ and ROI, as well as between BDS and ROI. Based on the results obtained $\mathrm{HO}_{1}, \mathrm{HO}_{2}, \mathrm{HO}_{3}$, and $\mathrm{HO}_{4}$ are therefore rejected similar to the findings of J. Paul (2017), K.I. Al-Daoud, Saidin and Abidin (2016); Mululu (2005).

By way of recommendation, shareholders and other stakeholder should demand complete director's report at Annual General Meetings to ensure that directors' attendance at board meetings will be open to public scrutiny. Also as Board activity/attendance of Board meetings has proven to be a strong predictor of firm performance shareholders can rely on the attendance of board meetings by board members and size of the board in guiding their expectations and making comparisons between their investments in various companies. Also shareholders should de-emphasize firm size and age of company in taking investment decisions as both have proven to be insignificant in determining the Returns on Investment. With regard to novelties, future studies can consider other measures of board effectiveness such as board diversity and Number or frequency of meetings. Similarly, future research works in this regard would do well to use a larger sample. Although, this has utilized ROI as a measure of firm performance other non-financial measures can be considered in future research works.

\section{References}

Adams, R. B., \& Mehran, H. (2003). Is corporate governance different for bank holding companies? Available at SSRN 387561.

Akinleye, G. T., \& Fajuyagbe, B. S. (2019). Corporate governance and financial performance: an empirical analysis of selected multinational firms in Nigeria. Problems and Perspectives in Management, 17(1), 11.

Al-Daoud, K. I., Saidin, S. Z., \& Abidin, S. (2016). Board meeting and firm performance: Evidence from the Amman stock exchange. Corporate Board: Role, Duties and Composition, 12(2), 6-11.

Alley, I. S., Adebayo, A. L., \& Oligbi, B. O. (2016). Corporate governance and financial performance nexus: any bidirectional causality? International Journal of Management and Economics, 50(1), 82-99.

Arouri, H., Hossain, M., \& Muttakin, M. B. (2014). Effects of board and ownership structure on corporate performance. Journal of Accounting in Emerging Economies.

Botchkarev, A., Andru, P., \& Chiong, R. (2011). A Return on Investment as a Metric for Evaluating Information Systems: Taxonomy and Application. Interdisciplinary Journal of Information, Knowledge \& Management, 6.

Chassagnon, V., \& Hollandts, X. (2014). Who are the owners of the firm: shareholders, employees or no one? Journal of Institutional Economics, 10(1), 47-69.

Chaudhary, N., \& Gakhar, K. (2018). Corporate governance and financial performance with a perspective on board size and frequency of board meetings: Empirical evidence from india. Drishtikon : A Management Journal, 
9(1), 37.

Du Plessis, J. J., Hargovan, A., \& Bagaric, M. (2010). Principles of Contemporary Corporate Governance, 2nd Edt.

Fama, E. F., \& Jensen, M. C. (1983). Agency problems and residual claims. The journal of law and Economics, 26(2), 327-349.

Fatihudin, D., \& Mochklas, M. (2018). How Measuring Financial Performance. International Journal of Civil Engineering and Technology (IJCIET), 6(9), 553-557.

Financial Reporting Council (FRN) of Nigeria, 2018. National Code of Corporate Governance. Retrieved from.www.frcn.org. (Accessed 29 Jan 2020)

Grossman, S. J., \& Hart, O. D. (1986). The costs and benefits of ownership: A theory of vertical and lateral integration. Journal of political economy, 94(4), 691-719.

Haque, F., \& Arun, T. (2016). Corporate governance and financial performance: an emerging economy perspective. Haque, F. \& Arun, TG (2016). Corporate governance and financial performance: an emerging economy perspective. Investment Management and Financial Innovations, 13(3), 228-236.

Jensen, M. C., \& Meckling, W. (1976). H.(1976). Theory of the firm: managerial behavior, agency costs and ownership structure En: Journal of Finance Economics, 3.

Letza, S., Sun, X., \& Kirkbride, J. (2004). Shareholding versus stakeholding: A critical review of corporate governance. Corporate Governance: An International Review, 12(3), 242-262.

McKinsey (2002), McKinsey Global Investor Opinion Survey on Corporate Governance- Key findings, www.mckinsey.com

Mululu, A. K. (2005). The relationship between board activity and firm performance: A study of firms quoted on the Nairobi Stock Exchange. Unpublished MBA project. University of Nairobi.

Newey, W. K., \& West, K. D. (1987). Hypothesis testing with efficient method of moments estimation. International Economic Review, 777-787.

Ntim, C. G. (2009). Internal corporate governance structures and firm financial performance: evidence from South African listed firms (Doctoral dissertation, University of Glasgow).

OECD (2004), Principles of Corporate Governance, www.oecd.org

Patel, M. A. (2018). Corporate governance and financial performance in an emerging economy context: Evidence from pakistan's food, personal care and cement sectors. South Asian Journal of Management, 25(1), 1-16.

Paul, J. (2017). Board activity and firm performance. Indian Journal of Corporate Governance, 10(1), 44-57.

PriceWaterhouseCoopers. (2015). Corporate Governance in the Boardroom A practical perspective. Retrieved from https://www.pwc.com/ee/et/publications/pub/corporate-governance-in-the-boardroom.pdf.

Rashid, A. (2011). Corporate governance in Bangladesh: A quest for the accountability or legitimacy crisis. Research in Accounting in Emerging Economies, 11(1), 1-34.

Samson, O., \& Tarila, B. (2014). Deposit money banks and economic development in Nigeria. Financial Assets and investing, 1(1), 41-50.

Siddiqui, S. S. (2015). The association between corporate governance and firm performance-a meta-analysis. International Journal of Accounting and Information Management.

Sheikh, N. A., Wang, Z., \& Khan, S. (2013). The impact of internal attributes of corporate governance on firm performance: Evidence from Pakistan. International Journal of Commerce and Management, 23(1), 38-55.

Shiah-Hou, S. R., \& Cheng, C. W. (2012). Outside director experience, compensation, and performance. Managerial Finance.

Smith, A. (1937). The wealth of nations [1776].

Sullivan, J. D. (2009). The moral compass of companies: Business ethics and corporate governance as anticorruption tools. Focus, 7, 47791 .

Tshipa, J., Brummer, L. M., Wolmarans, H., \& Du Toit, E. (2018). The effect of industry nuances on the relationship between corporate governance and financial performance: Evidence from South African listed companies. South African Journal of Economic and Management Sciences, 21(1), 1-18.

Vagneur, K. (2017). Corporate Governance. (2nd ed.). Edinburgh: Edinburgh Business School.

Van Horne, J. C., \& Wachowicz Jr, J. M. (2001). Principles of Financial Management. 